\title{
Politicizing the Environment in the Urban Century
}

\author{
Document Version \\ Proof
}

Link to publication record in Manchester Research Explorer

\section{Citation for published version (APA):}

Ernstson, H., \& Swyngedouw, E. (2019). Politicizing the Environment in the Urban Century. In H. Ernstson, \& E. Swyngedouw (Eds.), Urban Political Ecology in the Anthropo-obscene: Interruptions and Possibilities (pp. 4). (Questioning Cities). Routledge.

\section{Published in:}

Urban Political Ecology in the Anthropo-obscene

\section{Citing this paper}

Please note that where the full-text provided on Manchester Research Explorer is the Author Accepted Manuscript or Proof version this may differ from the final Published version. If citing, it is advised that you check and use the publisher's definitive version.

\section{General rights}

Copyright and moral rights for the publications made accessible in the Research Explorer are retained by the authors and/or other copyright owners and it is a condition of accessing publications that users recognise and abide by the legal requirements associated with these rights.

\section{Takedown policy}

If you believe that this document breaches copyright please refer to the University of Manchester's Takedown Procedures [http://man.ac.uk/04Y6Bo] or contact uml.scholarlycommunications@manchester.ac.uk providing relevant details, so we can investigate your claim.

\section{OPEN ACCESS}




\title{
1 \\ POLITICIZING THE ENVIRONMENT IN THE URBAN CENTURY
}

\author{
Henrik Ernstson and Erik Swyngedouw
}

\section{Introduction}

This book seeks explicitly to engage with the pressing question of how to organize anew the articulation between emancipatory theory and political activism. With the accelerating process of planetary and socio-ecologically deeply uneven urbanization at the turn of the twenty-first century, combined with growing geopolitical tensions and the rising legitimacy of all manner of identitarian and populist xenophobicnationalist movements, we are confronted with urgent challenges on how to think about and engage in emancipatory and political socio-ecological transformations. In a world marred by rapid but unevenly truncated socio-ecological disintegration, the accelerating triaging of people according to their location, socio-cultural inscription, and political-economic capabilities, and rising forms of all manner of political and ecological violence, the real possibilities of creating a world and city along more equal, free, and ecologically saner trajectories seem more remote than ever. Nonetheless, in recent years political discontent and protests by activists of a variety of ideological stripes and colours have cut through the promises of the fantasy of a cosy, neoliberal, smart, sustainable, resilient and democratically inclusive world that the elites and other architects of the present socio-ecological disorder increasingly and desperately portray as the only possible world to come. The choreographies of these protests against the prevailing socio-ecological order vary from extreme right-wing anti-establishment and nativist populism to new forms of progressive and emancipatory politics, often in conjunction with a cornucopia of grassroots movements and widely varying experimentations with alternative socioecological practices. This book navigates a course within the interstices of this parallax of increasingly desperate socio-ecological conditions on the one hand, and the political hopes embryonically manifested by radical democratizing insurgents and activists on the other. 
We contend that urban political ecology (UPE) can offer pathways to think through this situation and create possible openings for and strategies aimed at realizing potential emancipatory horizons. Since its early days, signalled by the 1996 article The City as a Hybrid (Swyngedouw, 1996), and ten years later, the edited volume In the Nature of Cities (Heynen, Kaika, and Swyngedouw 2006), UPE has matured through the proliferation of both empirical research and theoretical contributions that focus on the uneven urbanization of nature, the socio-ecological inequalities that pattern cities, and the perplexing socionatural landscapes that capitalist urbanization produces within, between, and beyond cities. In addition to many other contributions (see for instance, Keil 2003; 2005; Gandy 2005; Swyngedouw and Kaika 2014; Swyngedouw 2015), UPE has developed, together with scholars and activists worldwide, a rich conceptual apparatus to consider how the interrelated web of socio-ecological relations that span from the local to the global can be politicized. UPE has focused primarily on how social forms of power transform the environment and how the nonhuman becomes actively enrolled in processes of uneven and combined socioecological production and reproduction. UPE's key ambition has been to tease out who benefits and gains from these mutations and on tracing how cities are shot through and shaped by socio-spatial and socio-physical processes that also co-produce discourses and ways of knowing nature, society, justice, and forms of rationality. Against mainstream techno-managerial renderings of ecology as "natural" and "the urban" as essentially "social," devoid of material agency and biophysical vibrancy, UPE provided ways to comprehend "the urbanization of nature" as an inherently socio-material and hybrid form of metabolism, whereby social categories such as capital, money, norms, gender, and race are intimately interlinked with material assemblages as in the built environment, urban green spaces, or flows of water, food, energy, and other non-human matter. Indeed, UPE was an early contributor to what became known as the "material" turn in the social sciences and humanities (see, for example, Bennett and Joyce 2010; Hicks and Beaudry 2010; Pellizzoni 2016). Its main method has been to develop historically and geographically grounded, but theoretically informed, case studies that have served to articulate a socio-ecologically informed critique of different forms of oppression and exploitation of people and environments (Kaika 2005; Njeru 2006; Ranganathan 2014; Silver 2015). Throughout this period, UPE has systematically sided with activists to unearth, construct, and build narratives that render legible the intimate solidarities that bind together collective action and emancipatory processes in the direction of more equal and ecologically more viable communities. As such, UPE has asserted itself as a key mode of critical enquiry with recent review articles showing how it has expanded beyond its critical geographical and Marxists roots by embracing feminist, postcolonial, intersectional, and queer analyses (Truelove 2011; Gandy 2012; Lawhon, Ernstson, and Silver 2014; Heynen 2014; 2015; 2017; Rademacher 2015; Doshi 2016). Over the past two decades or so, hundreds of doctoral students have chosen UPE as their intellectual home and they have spawned a wide range of rich 
case studies and sophisticated theorizations, varying from, for instance, studies of urban food, water, and sanitation activism, studies tracing expansive planetary geographies of mining and energy that shape urban outcomes, to the worlding practices of housing activism that stretch across the global South and North in ever-complex ways. Indeed, scholars from diverse epistemological perspectives, but with a shared interest in the pivotal role of urbanization, a commitment to critical analysis, and a passion for emancipatory transformation, have contributed to lively debates and inspired, and been inspired by, a new generation of political and social activists whose political vision embraces the pursuit of egalitarian and socio-ecologically grounded emancipation.

However, the field is also in crisis, and it shares this with critical and radical theory more generally. As scholars and students of UPE and related fields, we have improved our ability to trace socio-material flows and hybrid objects like water, waste, and food. We explored how financial capital operates across scales, how economic crises unravel social cohesion and wreak ecological havoc, how the presence of (neo)colonial patterns of resource extraction combined with the exploitation of people shape the environment, and just how unequal and unsustainable the world has become. Nonetheless, we have less to offer in terms of what to do, in terms of thinking with radical political activists about new political imaginaries, forms of political organizing, and practices of emancipatory socio-ecological change. With planetary and uneven urbanization, the emergence of a multi-polar world order, pervasive socio-ecological change and deepening and sophisticated forms of depoliticization, there are real challenges on how to think emancipation today and how to organize the relation between emancipatory theory and political activism under urban conditions prevailing in the twenty-first century. The idea that critical urban and social theory can be politically performative, that is, that our intellectual labour can articulate with actually existing socio-political practices to make possible emancipatory ruptures and build progressive and liberating socio-ecological movements, is no longer self-evident (if it ever was) in our world of post-political neoliberal consensus on the one hand, and new radical politicizing movements in cities on the other (see Dikeç and Swyngedouw 2017). This book revolves around this task: what could emancipatory politics be about in our time? What does a return of the political under the aegis of equality and freedom signal today in theory and in practice? How do political movements emerge that could re-invent equality and freedom as actually existing socio-ecological practices?

\section{A necessarily obscene interruption}

This book combines critical geography, urban studies, and political theory to deal with this challenge. It does so through mobilizing the figure of "the AnthropoobScene," to recognize explicitly that we live in a cyborgian web of human/ non-human entanglements, but also to undermine the utterly depoliticized concept of "the Anthropocene." While we need to recognize the world as thoroughly 
constituted by the interweaving of human, technological, and non-human constellations and assemblages, the current popularization of the mainstream discourse of the Anthropocene renders a wide set of political imaginaries unthinkable. The "obscene," with its origin in classic Greek theatre's ob-skene, signified acts deemed inappropriate and too disturbing to be shown explicitly on stage, like violence, sex, deep anguish, or fear. In spite of this taboo, however, the spectator was still uncannily aware that these obscene acts were taking place, but off the stage, outside the field of vision. Our stuttering term, the Anthropo-obScene, serves to hack, while rendering insightful, just how the Anthropocene has inaugurated a world stage through which orderly narratives of management, science-based intervention, and capital can come together to save Earth, people, and the economy as we know it. ${ }^{1}$

It is absolutely crucial to understand our predicament not primarily in social or ecological terms, but in political terms. Even before posing the centennial question "What is to be done?" we need to ask-what can be done? This boils down to finding the ways and practices by which to make egalitarian politics possible (again) and to grapple with, in this particular historical junction, the significance of the Anthropocene in strictly political terms. Following Bonneuil and Fressoz (2016), this means first to recognize how the "shock of the Anthropocene" deepens depoliticizing tendencies. Across a range of fields, from science, arts and humanities, "The Anthropocene" is now deployed to proclaim that profound change is afoot and that we live in a time of radical newness which requires new technologies, new forms of governance, and new ontologies and cosmologies. This proclaimed truth of the Anthropocene, morally and scientifically, inaugurates the necessity of radically new institutional and technomanagerial dispositifs that can assure the continuation of civilization as we know it. In other words, we are summoned to change things radically to make sure that nothing really has to change!

We know that humanity's newly acquired geo-agency, what the Anthropocene is referencing, is intrinsically entwined with the process of capitalist planetary urbanization. The elite's pursuit of earthly gain by roaming the Earth and rummaging through its innards, and the concomitant commodification of everything, nurtured the process of planetary urbanization and produced the uneven and combined socio-ecological dynamics that mark the unequal eco-geographies of the world (see Chapters 2 and 3). Indeed, the widening and socio-ecologically embedded circulation of capital and its racial, gendered, and class dynamics was and is predicated upon intensifying proliferations of metabolic vehicles that transform non-human "stuff" and re-order human/non-human assemblages in uneven ways and with profound socio-ecological implications.

One good example of how the discourse and the materiality of urbanization in the Anthropocene intersect, lies in the pumped-up popular and academic discussions of how information technologies and the purportedly de-materialized affective economies, including social media, Twitter, Instagram, Uber etc., would render urban development "smart" and "sustainable." While portrayed as useful 
for distributed and big data informatics in planning transport and saving energy, there is a much darker side to these ICT technologies, discernible in the highly materialized and uneven set of practices that includes the exploitation and circulation of a range of minerals. These include the "Unobtanium"-like-mineral Coltan, used for producing micro-sized tantalum capacitors in mobile phones and almost any other compact electronic device. Named a "conflict-prone mineral" for its role in funding domestic militias and foreign armies that fight over the control over its feverish extraction, Coltan's dehumanizing production chains have destroyed landscapes, rivers, and working bodies in already socio-ecologically vulnerable places in D.R. Congo, Rwanda, and Burundi, superimposing neo-colonial practices on to persistent colonial relations. ${ }^{2}$ Furthermore, at the end of the life-span of these devices, which for a cell phone is now down to $2-5$ years, the "recycling" process of tantalum and other materials returns to these regions as toxic e-waste, dumped and handled by often marginalized people in cities like Lagos and Mumbai-or Guiyu in China, where children have been measured with higher levels of lead in their blood because of the city's concentration of imported e-waste. ${ }^{3}$ The material underbelly of the virtual worlds of Tweets, Instagram videos, or Uber-calls, and fantasies of smart urbanism, reveals a dystopian and ruinous socio-ecological landscape.

This geographical tracing, from a phantasmagoria discourse to brutal material realities, only goes to show how uneven planetary urbanization is a key driver of anthropogenic climate change and other socio-environmental transformations, including biodiversity loss, soil erosion, deforestation, ocean acidification, the accumulation of micro- and nano-plastics, resource extraction and deep-geological mining, the construction of large dams and energy plants, and the galloping commodification of all manner of natures. What is not contested at the level of global policy, indeed a consensus prevails, is that our urban fate and natures' transformations are irrevocably bound up in an intimate and intensifying metabolic symbiosis. It is indeed precisely because these deteriorating socio-ecological conditions could very well jeopardize the continuation of civilization as we know it, that urban metabolism has been elevated to the dignity of a global public concern - and where strong mechanisms of consensus-making and depoliticization set in.

Coming full circle, and in the face of these consensually recognized challenges, a global urban academic and professional technocracy has spurred a frantic search for a "smart" socio-ecological urbanity including buzz-words such as eco-development, retrofitting, sustainable architecture, adaptive and resilient urban governance, inter-species eco-topes, ecosystem services, and innovativebut fundamentally market-conforming-eco-designs. These techno-managerial dispositifs, experimented with in science labs and splashed out in design magazines, art books, exhibitions, and policy documents, should, however, not simply be taken for what they claim to be. Rather, we need to critically also understand them as a response from a global reactionary elite (which includes not merely the $1 \%$, but through silent consent, also urban middle and professional classes) that searches frantically for eco-prophylactic remedies. This thick canopy of techno-managerial languages and practices is like the soft inside of 
a TV-commercial, promising redemption while insisting that no real change is necessary or even possible. Moreover, such language binds together academic, policy, and business sectors so that the hegemonic public discourse through which global warming, run-away ecological crises, and inequality are addressed, conveniently tries to hide and off-stage the profoundly capitalist and socioecologically unequal realities of our predicament. Indeed, under a metaphorical billboard of radical techno-managerial restructuring, the focus is now squarely on how to sustain capitalist urbanity so that nothing really has to change!

In addition to this techno-managerial form of depoliticization, there is another project afoot which is arguably more tricky and difficult to analyse critically, but with potentially profound consequences. In recent years, scholars have proposed and developed new materialist and symmetrical relational ontologies, including object-oriented, more-than-human, and post-human perspectives (see e.g., Stengers 2003; Latour 2005; Morton 2013; Harman 2016). While the analytical intent has been to distribute agency beyond humans and overcoming rigid and binary nature-society dichotomies, an ambition shared by UPE since its inception, we argue in Chapter 2 (see also Chapter 4; Swyngedouw and Ernstson 2018) that such symmetrical frameworks also risk (albeit by no means necessarily or intentionally so) becoming hijacked into political-economic imaginaries that have less to do with ethical caring for more-than-human constellations, and more with a hysterical attempt at sustaining hyper-accelerationist eco-modernist visions. While embracing a more reflexive and symmetrical socio-ecological cosmology, big science, geo-engineering, and big capital could more easily gesture to save both Earth and Earthlings.

Broadly phrased in this way, the intellectual work that we hope our stuttering term "the Anthropo-ob(S)cene" will do is one of interruption, of rendering present that ghostly spectral side of reality that is presently off-staged and where political possibilities for the construction of more equal and free environments reside. Indeed, the Anthropo-obScene works to disturb and rupture the consolidation of a particular view of conceptualizing, framing, and managing global and local ecological crises and problems, while fully and radically embracing a cyborgian human/non-human world. Within the recast frame of the AnthropoobScene, we contend that a whole set of situated, but geographically and culturally interlinked modes of politics, become not only possible, but practical and necessary.

\section{Seismic transformations of earthly dynamics}

Our obscene interruption and the chapters from our contributors have to be placed within a wider socio-ecological and quickly changing context. We identify five major transformations that are shaping contemporary earthly dynamics within which lurk both the constraints and possibilities for emancipatory struggles. While a more nuanced development would be preferable, we sketch below how these transformations can help to frame key challenges that UPE and associated 
fields are facing to remain relevant in producing both knowledge and political possibilities.

First, the process of socio-ecologically uneven planetary urbanization is still little understood in UPE, especially in relation to the political as defined above. How are international and radically democratic political movements built today? From what (urban) spaces, socio-ecological contexts, subjectivities, and interruptive events could political movements emerge? Significant scholarly effort has been expended to trace global socio-ecological flows and networks that are constitutive of the geographical imprint produced through the unfolding of capital's geo-agency (see e.g., Brenner and Schmid 2014; Arboleda 2016). However, within UPE and elsewhere, less attention has been paid to its associated deepening depoliticization-or, and perhaps more crucially, to considering its political and emancipatory possibilities.

Second, there has been a worrying proliferation of geopolitical tensions and geo-ecological conflicts that influence political movements in not easily discernible ways. These tensions are often structured around territorially constituted identities that render the "world order" precarious and unstable, including, for instance: the Syrian wars, ISIS, and the growing number of refugees that migrate to Lebanon, Turkey, and the EU; tensions over artificial islands in the South China Sea; the possible breakdown of the Iran nuclear deal; risk of disintegration of Nigeria; and the rise of "strong" leaders and identitarian, racist, nationalist, and fascist mobilizations in several countries, both North and South. Consider, for instance, also the rise of China as it seeks to secure its future demands for materials and energy in Africa, Latin America and elsewhere, often in exchange for investments in urban infrastructure, ports, and railways (see e.g., Corkin 2011). While UPE and associated fields have studied these dynamics through the dialects between corporate-led integration of neoliberal globalization on the one hand, and the fragmenting forces engendered by intensifying inter-place and inter-state conflict on the other, there are surely novel dynamics entering the mix in an increasingly multi-polar world where Bretton Woods and UN-institutions have less of a grip, and where the megacities of Delhi, Mumbai, Shanghai, São Paulo, and Lagos surpass older "world cities" in both size and economic power. What is the fate and role of urban spaces and ecologies and what new political fault lines are generated; and who benefits from this apparent "unstable" and "insecure" world order?

Third, and connected to the former, a slowly but increasingly felt seismic wave is unfolding in the knowledge sphere when, as Achille Mbembe $(2017,1)$ recently put it, "Europe is no longer the centre of gravity of the world." For centuries, the West was the cradle of thought, the producer of hegemonic discourse, the universalized "no-place" from where narratives about the world were launched and diffused. Alongside ships, men, guns, and powder-and later accompanied by engineers, advanced technologies, and development aid - the West's self-image was bound up in an imperial project, which in turn served as an excuse for the violence at the frontier of this project: the mass enslavement of black peoples of Africa, the land dispossessions from Indigenous peoples in the Americas, Asia, Africa, Middle East and Oceania; and the extinction of peoples and ways of knowing (James 1989 
[1938]; Fanon 1963; Said 1983; Wynter 1995; Mamdani 1996; Lalu 2009; Mignolo 2012). In parallel to the return of the ghosts, spectres, and resistances of this history, China, Singapore, Brazil, and India are now emerging as global publication powerhouses, while Western schools of thought are being provincialized and decentred (see e.g., Comaroff and Comaroff 2011; within UPE and urban studies, see Ernstson and Sörlin, forthcoming; Lawhon, Ernstson, and Silver 2014; Roy 2014; Robinson 2016). Postcolonial, Indigeneity, decolonial, and black radical thought, which have all produced crucial critiques of racial capitalism and colonial legacies, and their intimate association with modernity, have entered much more centrally in academic and political debates on environmental, urban and Anthropocene issues (see Chapters 2, 4, 5, 7, and 9; and Garuba 2012; de la Cadena 2015; Green 2015; Heynen 2015; Schulz 2017). What does this seismic shift of (finally) decentring Europe mean in relation to thinking politics? What does it mean in terms of politicizing the environment and life itself? It is crucial to remember here that this shift is not just about knowledge production but is to some extent also accompanied by the emergence of several imperial projects. We are now effectively sharing a world in which there are several ongoing imperial projects that in overlapping and competing ways aim to extract resources and project influence over distant territories (Roy and Ong 2011; Roy 2014). Given this distinctly political-ecological situation, UPE and associated fields need to engage with how these complex and contentious re-workings of material ecologies and cultural epistemologies influence the living world and the spaces we inhabit — and ask what possibilities for social and political movements emerge or exist.

Fourth, and in spite of an increasingly complex geopolitical situation, we should hold on to a wider interpretative optic to understand how big science and the Anthropocene discourse, a supposedly global caring for the world and all its critters, articulate with a deepening of neoliberal logics and the strengthening of immunological biopolitical governance (Chapter 2, building on Esposito 2008). "Immunological" is here understood as "the suspension of the obligation of mutual communal gift-giving" (ibid.) that conjoins with the (neo)liberal injunction to enjoy individual freedom and choice. This wider optic helps to uncover how the search for "smart cities" and other eco-prophylactic remedies by the elites and professional classes produce vast new urban and suburban geographies with an intimate and "civilized" inside wherein "sustainability" is taken very seriously and debated, while creating its own constitutive outside. This is wellillustrated by so called "eco-estates" in South Africa (Ballard and Jones 2011; Baigrie and Ernstson 2017). These are well-guarded and gated housing estates for the super-wealthy, and predominantly white, and are built under the guise of ethically caring for the environment through all manner of environmental consumerism, while cocooning its inhabitants to remain politically blinded to the fact that their "sustainable" lifestyle is bought at the extraordinarily high price of producing unsustainability elsewhere. The latter is marked by a continuation of capitalist-colonial violence on black bodies, including women, men, and children in the same city who cannot easily access electricity, sanitation, water, or a 
good basic education (Huchzermeyer 2003; Neocosmos 2012; Benson 2015). In building these "e-pods," environmental arguments and eco-gentrification function as a cover-up while normalizing neo-, or eco-apartheid urban development. This is played out on a global scale, too, where uneven and combined socio-ecological change keeps intensifying, in part nurtured by the frantic search for eco-prophylactic techno-machineries that ostensibly are engineered to better manage a supposedly "sustainable" future, but which often serve to deepen commodification of both human and non-human "stuff" including human organs, babies in surrogate mothers, genomes, land, rivers, and the atmosphere. This unfolds in parallel to the small coterie of super-wealthy and a minority of well-off "Earth transformers" that are increasingly capable of living in phantasmagorical immunological sanctuaries - the e-pods - of "sustainable" and "smart" enclaves. We need to be attentive to how the elites and professional classes, across nationalist and ethnic signifiers, are carving up the world and the living and in what ways the urban/suburban/peri-urban become crucial spaces for the enactment of this wider transnational dynamic (see Chapter 9). How is capital mobilized to bend the rules and change public discourse (see Chapter 5)? How does this particular class-project that nurtures a "sustainable urbanism" of and for the few, while investing lots of energies in creating cosy consensual narratives, materialize on the ground (see for instance Chapters 2, 5, and 13)? A wider material and discursive critique is necessary and political ecology as academic discipline and mode of organizing can play a significant role in fostering such a critique.

Despite the magnitude of the abovementioned four dynamic shifts, our fifth and final point focuses squarely on bringing back the political, a focus on politicization, which represents what is most central to this book. It is also the one that UPE and associated fields have downplayed for too long. We contend this is the gap that requires most attention. The last few decades have been characterized by profound processes of depoliticization that have to be clearly defined and scrutinized. On the one hand, the neoliberal idyll of a globally integrated and perfectly commoditized world operating in everyone's best interest is sustained, among others, by a fantasy held of an inclusive and democratic configuration in which everyone can be who they want to be and express different positions and perspectives in institutional settings that nurture participatory and pluralist encounters. On the other hand, radical disagreement and dissensus about the configuration of the present order, whether voiced by radical egalitarians, right-wing populist or religious fanatics, is censored, rendered unacceptable, and placed outside the "inclusive" liberal democratic order. We are thus approaching an idealized situation in which everything seems to be politicized, i.e. everything can be rendered contentious, yet radical disagreement and the expression of antagonistic socio-political positions is either banned completely, meets with cynical rejection, or regarded with great suspicion. These antagonistic positions nonetheless demonstrate the profound heterogeneities that cut through the social. It is precisely these constitutive antagonisms that are captured by the signifier "the political" and which must hold greater currency in how we think urban political ecology. 
"The political" is the name that stands for the recognition of the antagonisms that cut through the social. The political manifests itself in moments or events of interruption of or rebellion against the instituted order of actually existing politics (see, Marchart 2007; Wilson and Swyngedouw 2014). It is "the political" that prevents a fully closed, harmonious, and fully ordered society. The disavowal, repression, or foreclosure of the recognition of such constitutive antagonism is what the term "depoliticization" refers to. Post-politicization is, therefore, the mobilization of a series of strategies, procedures, and techno-managerial arrangements that suspend, colonize, or ignore the dimension of "the political" as defined above. Politics, in contrast, refers to the daily choreographies of instituted politics and policy-making, including the actors, institutional forms and procedures, and the management of recognized contentious issues. So, while democratic politics as organized dispute is very much alive and legitimized as the institutional corollary to global ecological and economic integration, the political is increasingly colonized by instituted forms of "doing politics," which, as we argue in Chapter 2, is further amplified by the particular way the Anthropocene has been symbolized and operationalized.

Taken together, these five seismic transformations point at the need for a shift of the intellectual gaze of UPE and associated fields. Rather than tracing yet another socio-material flow or applying yet again a cyborgian perspective of the urbanization of nature, we need to more explicitly address the question of "the political" if we are to contribute toward renewed and performative emancipatory processes (Chapter 14). Indeed, the birth pains of the politically sanitized term "the Anthropocene" raise urgently the spectre of the obligation to consider what sort of environment we wish to live in, how to produce it, and with what consequences. It calls for a political project that fully endorses cyborgian human/non-human entanglements and takes responsibility for their nurturing while insisting on the egalitarian presumption that undergirds any democratizing project. The central question, therefore, is not any longer about bringing environmental issues into the domain of politics as has often been the case until now, but how to bring the political into the environment.

\section{Thinking, engaging, politicizing}

This book and its contributors intend to engage with this field of changing dynamics, profound depoliticization, and egalitarian aspirations. The authors bring their wealth of experience from studies across the global South and North and mobilize neo-Marxist, feminist, postcolonial, and radical democratic frameworks. While there is considerable debate and difference among the contributing authors, they share the view that "the urban" is pivotal in interrupting mainstream discourses and practices and constitutes a privileged site within a wider complex of dynamics and structures to articulate their work with emancipatory practices. They also share a commitment to offer reflections on politicizing tactics and strategies. Indeed, our emphasis here is on how the dynamics of uneven planetary urbanization co-shape 
what is referred to as the Anthropocene-whereby our notion of the AnthropoobScene is mobilized in an attempt to foreground what is being silenced and to suggest possible avenues for re-politicization. To this end, the book is organized along three axes that intersect and communicate with each other:The Political,The Situated, and The Performative.

Part I on The Political interrogates how the conceptualization of the Anthropocene in its various alternative formulations may actually contribute to deepening the ongoing process of depoliticization, while searching for theoretical ways to encounter egalitarian practices that confront our socio-ecological predicament. While urbanization was always predicated on the extraction of material resources beyond the city proper and producing significant metabolic rifts, this has arguably reached a new scale and intensity in the present process of planetary and uneven urbanization. Part I explores and discusses how these processes operate discursively, ideologically, materially, and in terms of political promises.

In Chapter 2, we develop and deploy the term "the Anthropo-obScene" and argue that various discourses on the Anthropocene have created a set of stages that disavow certain voices and ways of seeing by rendering some forms of acting (human, non-human, and more-than-human) off-stage. We interrogate how the symmetrical more-than-human ontologies also open up a possible articulation with techno-managerial discourses that deepen what Roberto Esposito (2008) has called an immunological biopolitics, the always failing attempt to immunologize life from harmful intruders or potential disintegration. With the Anthropo-obScene, we seek a politicization of the socio-ecological conundrum we are in, while fully and radically embracing our interdependence with non-humans.

Richard Walker and Jason W. Moore continue in Chapter 3 to tackle the enigma of nature within an expansive reading of Marxian political economy while mobilizing both historical and contemporary examples. The fate of the Earth is deeply bound up with the accumulation of capital, or what they call "the capitalist vortex," and they argue for a better integration in Marxist economics of how nature serves as a source of surplus to feed the vortex. Labour and nature are indelibly joined in the production of "free gifts" that come via three frontiers of capitalist expansion-primitive accumulation, commodity production, and capitalization - that proceed along three geographic frontiers across the face of the Earth: extensive, internal, and intensive. They provide theoretical tools to understand why capitalist growth has, for 500 years, meant inexorable extraction, depletion, and devastation of natural resources, while producing landscapes of profit. In this re-booting of a materialist reading, the authors provide a background to understand many of the geographies, ecologies, and struggles that the book grapples with.

In the final chapter of Part I, Chapter 4, Andrés Henao Castro and Henrik Ernstson engage with postcolonial theory as a departure point to interrogate the discourse of the Anthropocene and its depoliticizing effects. They maintain that the way that the Anthropocene discourse has been articulated within parts 
of postcolonial theory is deeply problematic and risks making the political categorically unthinkable and ontologically evacuated. In an attempt to disrupt this deadlock, the authors combine post-foundational and postcolonial theory to propose three performative interruptions against conditions of exclusion-the politics of time, the politics of translation, and the politics of the stage. These build to re-launch the political performativity of subaltern experiences in the here and now.

Part II, The Situated, counterbalances an often-misplaced focus on the planetary by exploring how radical democratic responses and politicization of environments are necessarily also locally articulated with identifiable spaces and shaped by historical, regional, and everyday experiences and struggles.

Part II starts with Malini Ranganathan and Sapana Doshi in Chapter 5, who examine ecological dispossession in the Anthropocene through the rise of anticorruption movements in urban India, which in quite surprising ways have politicized a central mechanism of private wealth creation through the grabbing, or robbing, of public (wet)lands. With its long discursive career in the post-colony, the authors argue that corruption continues to be a fraught ethico-political terrain in which both emancipatory and regressive tendencies are embedded. Placed within the historical and geographical context of a rapidly growing city and a geopolitically increasingly assertive India, the chapter considers head-on urban socionature under "advanced capitalism," the collusion between the super-wealthy and the state, and the hopes for egalitarian ruptures and movements.

Following from this, Nik Heynen, in Chapter 6, argues for paying more attention to deep urban history to better understand the connection between racial capitalism and urban space in order to unravel who decides who will have access to, and who will be excluded from resources or other components of the environment. By excavating the political ecological history of Atlanta, a city in southern USA, he creates a powerful argument for an "abolitionist urban political ecology" that pairs African-American political thought with UPE to enrich contemporary progressive struggles for antiracist socionatural change. Resonating with AbdouMaliq Simone's (2011) "black urbanism," he shows that when those who were always excluded from the making of the official city articulate themselves as the centre, interruption and proper politics can follow.

Deepening our understanding of the continuation of racialized capitalism, Jonathan Silver in Chapter 7 combines a distinctly socionatural perspective of urbanization with Frantz Fanon's (1963) analysis of the violence of colonization as "suffocation." A form of suffocation of identity, ways of knowing and ability to live at all was imprinted in the way the relation between colonizer and colonized became structured. Silver urges us to see how mechanisms of suffocation are continuing today in the ways climate change and global policy are translated as "adaptation" and market-based "solutions" in three cities of Africa: sea-level rise in the coastal city of Saint-Louis, Senegal; vulnerable electricity infrastructures in Accra, Ghana; and, focusing on a World Bank-funded waste management programme in Mbale, 
Uganda, how global policy on lowering greenhouse gas emissions undermined the municipality's response to climate change, while privileging international actors and financial markets. Drawing on these contemporary experiences, he reads the urban spatiality of climate change as "social-ecological violence" that nurtures the continuation of coloniality, a logic of excluding local knowledge and voices, and a deepening of racialized capitalism.

Continuing the unearthing of experiences that are not heard or sensed, Garth Myers in Chapter 8 develops a "multi-vocal" urban political ecology that takes seriously the "rogue" sensibilities of urban Africa in how environments can be politicized. Based on a wide reading of Africa's urban landscapes and a case study from Dakar, Senegal, a city demonstrating recent gentrification and continued expansion of self-constructed neighbourhoods or slums, he explores the tricky spaces of grassroots activism. Often constrained by heavy policing from one-party states and the risk of violent "ethnic" flare-ups and leadership vacuums, he sees a possibility for how environmental and political consciousness are merging, which could reduce violent confrontations without eliminating a push to make visible what has been off-staged and reframe how urban environments are known from its multiple peripheries.

Roger Keil expands the view from the peripheries in Chapter 9 to focus on how the historical production of vast suburban spaces across the world, from middle-class suburbia to self-constructed slums, are deeply tied up with the Anthropocene and its politics. He argues that while it is clear how suburbanism has been at the core of capitalist production - especially since the Second World War when it was exported from the USA to revive entire national economies in Turkey, India, and Chinascant attention has been paid to the suburban as a scale of cognition and terrain for political action. Drawing on works of art and scholarly literature, he critiques the now quite stale emphasis on (globalized, gentrified, normalized, densified) city cores as the location for politics and environmental savviness, and insists that suburban spaces are not static, conservative, and a-historical. Rather than evacuating "suburbia" from our political imaginaries, we need to pay more attention to understand the movements and possible urban political ruptures that suburbanization as a planetary condition harbours.

Following the cue of unearthing new locations from where to launch political ecological projects, Marco Armiero approaches the spectral lives of real and imaginary ghosts in Chapter 10. He unfolds a hauntology of the Anthropocene through the lens of the many presences of urban waste in Naples, from the rubbish and toxic pollutants in human and non-human bodies, to its revolutionary potential in how residents have organized to articulate new urban commons. Situated within the modern history of Italian political and environmental activism, which partly implicates himself as a ghostly presence, he also reflects on the differences between engaged and revolutionary researchers in the unfolding of the Anthropocene.

Taken together, these chapters propose new readings of the political, disturb the premises on which emancipatory politics is generally discussed, and provide 
material to glean the potential for new forms and modes of bringing the political into the environment across diverse contexts.

Part III on The Performative engages explicitly with political theory to forge new modes of scholarly, artistic, and activist collaborations between "the political" and "the ecological." It aims to make explicit possible coordinates for emancipatory politics in a cyborgian world of intense human/non-human entanglements.

Jodi Dean, in Chapter 11, focuses on innovative artistic and political practices that force division within public institutions, rather than consensus in relation to socioenvironmental crisis and global warming. She argues that the colonization of public institutions by private interests has taken deep roots. This has to be challenged not simply from the outside, but from within, reclaiming institutions (from science, art, education to government) in the name of democracy and equality. Learning from and with the art collective Not An Alternative, she interprets their ongoing performance of "The Natural History Museum." By adopting the legitimating aesthetics, pedagogical models, and presentation forms of natural history museums (within a real museum), they target the knowledge politics of anthropogenic ecological change to "activate" the natural history museum's claim to serve the common but in a manner that divides the museum from within: anyone connected to the museum sector, those tasked to communicate science and natural history, has to take a side. This clarifies and forces a choice: Do you stand with collectivity and the common, or do you stand with oligarchs, private property, and the fossil fuel industry? The Natural History Museum is thus an example par excellence of a politically performative and divisive democratic form of politics, which could and should proliferate and be up-scaled in that it both rejects the post-political apocalyptic imaginaries associated with climate change and creates publicly available egalitarian spaces.

In Chapter 12, and in resonance with previous and other contributors in the book (see Chapters 2, 4, 11, and 13), Andy Merrifield attacks the problems associated with the professionalization of life and with liberal democratic representation that generate a set of deep-seated flaws in tackling common problems. From the observation that we increasingly live "through a series of 'spectacular' images [...], messages, sound-bites," which we have allowed to speak for us and for our desires, he weaves in Guy Debord's analysis of the spectacle to re-equip it for its continuing politicizing relevance in late capitalism. He then interrogates three forms of representation-money, as the only measure of value; professional representation, as the paradigm of truth; and representative governance as the only form of democracy - and from this develops the idea of the amateur as the politically performative subject. "The people," or what Merrifield calls the "shadow citizenry" (those cast out of a professionalized neoliberal order, the 99\%), become the analytical and politicizing location from where a project can be launched to get at those professionals on the inside, forcing this private inside to be answerable to the public outside.

In the last chapter of Part III, Chapter 13, Maria Kaika embarks on a search for intellectual responsibility in the age of the Anthropo-obScene, what she calls 
a "scholarship of presence." She critiques the rapid ascent of "the Anthropocene" within humanities and social science, arguing that this emerging imaginary may be the most political thing about it. Even critical engagements add symbolic power and scholarly weight to a concept that contributes to the formation of a new master narrative that "naturalizes" capitalism, while foreclosing alternative processes of subjectification and possibilities for autonomy. By drawing on experiences from contemporary urban Greece, she traces how a renewed intellectual responsibility for the humanities, arts, and social sciences could be configured that instead focuses on co-researching and capturing processes of subjectification, claims and embodiment of re-commoning, and narrates resistance, hope, and alternative configurations, giving them symbolic and ontological gravitas. This scholarship of presence has a long history that pays equal attention to tedious details of everyday life, as it does in developing a broader intellectual and political project. We need to collect stories and data that can put flesh and bone onto abstract ideas. But we also need, as she writes, "to put in the hard labour and courage to symbolize emerging radical imaginaries in ways that can empower them to become narratives performative of creating a new future." This aims ultimately to participate in constructing "an archaeology for a new future" so that these experiences can start forming alternative master narratives.

\section{Concluding remarks}

This book seeks to explicitly engage the relation between emancipatory theory and political activism, on bringing back "the political."We believe that our contributors and the wider field of UPE can offer inspiration for this task given rapid urbanization and intensifying anthropogenic ecological change. Through introducing our notion of the Anthropo-obScene (further developed in Chapter 2) and discussing five dynamic transformations, we have also tried to set the stage for scholarly renewal. Indeed, in the concluding chapter of the book (Chapter 14), we draw on the various chapters to push for a closer engagement between critical urban environmental studies and political theory. This is aimed at nudging scholars to expand their terrain of academic endeavour to move from describing, analysing, and critiquing urban socio-ecological transformations and movements-as has been the staple of much of UPE and associated studies so far-to developing a vocabulary and grammar that can aid the task of developing politically performative theory and engaging with real existing political movements that are experimenting with the production of egalitarian spaces, elaborating new political subjectivities, and creating socio-ecological alternatives.

In sum, the book's main objective is to critique and engage with the wide range of knowledge practices that depoliticize the environment during an era when the environment requires more politicization than ever. Our main contention is that urban political ecology, as well as many other critical theoretical perspectives, in the way they became formalized, has ignored the thorny relationship between critical thought and progressive political action. This book is a contribution to the project 
of re-politicizing political ecology, and points, both theoretically and empirically, towards new political possibilities while humbly and hopefully offering beacons for radical and progressive studies for decades to come.

\section{Notes}

1 As we elaborate in Chapter 2, and in Henao Castro and Ernstson in Chapter 4, there are various ways to write and deploy this term, for instance Anthropo-Obscene, AnthropoobScene, or Anthropo-ob(S)cene, to emphasize different aspects of the depoliticizing figure of "The Anthropocene." See also Swyngedouw and Ernstson (2018).

2 For information on the Coltan and tantalum value chain and its tight connection to civil wars and socio-environmental destruction, see Sutherland (2011), Akiwumi and Hollist (2016) and Klosek (2018), among others. See also Demos (2015).

3 Although the average cell phone only contains about 40 milligrams of tantalum, which is extracted from Coltan, there were nearly 7 billion mobile phone subscriptions in 2015 according to Welfens, Nordmann and Seibt (2016), which amasses staggering circulation volumes. They continue by saying that less than $10 \%$ of mobile phones have been estimated to be recycled worldwide, with Barume (2016) adding that some 15-20\% of total tantalum is recycled. Most e-waste ends up in African and Asian cities (Tansel 2017) with increased lead levels in blood reported by Watson (2013).

\section{References}

Akiwumi, Fenda A., and Arthur O. Hollist. 2016."The New Kid on the Old Block: Coltan, Conflict-prone Minerals, and Post-war Reconstruction in Sierra Leone.” The Extractive Industries and Society 3(2): 316-319.

Arboleda, Martín. 2016. "In the Nature of the Non-city: Expanded Infrastructural Networks and the Political Ecology of Planetary Urbanisation." Antipode 48: 233-251.

Baigrie, Bruce, and Henrik Ernstson. 2017. "Noordhoek Eco-estates Protect the Rich from the Reality of Masiphumelele:Apartheid Geography Preserved Behind a Concern for the Environment." GroundUp, January 23, 2017. Cape Town. Accessed May 15, 2018. www. groundup.org.za/article/noordhoek-eco-estates-protect-rich-reality-masiphumelele/.

Ballard, Richard, and Gareth A. Jones. 2011. "Natural Neighbours: Indigenous Landscapes and Eco-estates in Durban, South Africa." Annals of the Association of American Geographers 101(1): 131-48.

Barume, Bali, Uwe Naeher, Désirée Ruppen, and Philip Schütte. 2016. "Conflict Minerals (3TG): Mining Production, Applications and Recycling." Current Opinion in Green and Sustainable Chemistry 1: 8-12.

Bennett, Tony and Patrick Joyce, eds. 2010. Material Powers. Cultural Studies, History and the Material Turn. London: Routledge.

Benson, Koni. 2015. "Three Hundred Years of Shackdwelling and Women's Organised Resistance in Cape Town." In Out of Order: Popular Mobilisation in Contemporary South Africa, edited by Richard Pithouse and Gary Minkley, 1-46. Fort Hare: Fort Hare University Press.

Bonneuil, Christophe and Jean-Baptiste Fressoz. 2016. The Shock of the Anthropocene. London: Verso.

Brenner, Neil, and Christian Schmid. 2014."Planetary Urbanization.” In Implosions/Explosions: Toward a Study of Planetary Urbanization, edited by Neil Brenner, 160-63. Berlin: Jovis. 
Comaroff, Jean and Jean L. Comaroff. 2011. Theory from the South: Or, How Euro-America Is Evolving Toward Africa. Boulder: Paradigm Publishers.

Corkin, Lucy. 2011. "Uneasy Allies: China's Evolving Relations with Angola.” Journal of Contemporary African Studies 29(2): 169-80.

de la Cadena, Marisol. 2015. "Uncommoning Nature.” E-Flux Journal 65: 1-8.

Demos, T.J. 2015. "V. Anthropocene, Capitalocene, Gynocene: The Many Names of Resistance." Still Searching, June 12. Accessed April 20, 2018. www.fotomuseum.ch/en/ explore/still-searching/articles/27015.

Dikeç, Mustafa, and Erik Swyngedouw. 2017. “Theorizing the Politicizing City.” International Journal of Urban and Regional Research 41(1): 1-18.

Doshi, Sapana. 2016. "Embodied Urban Political Ecology: Five Propositions." Area 49(1): 125-28.

Ernstson, Henrik and Sverker Sörlin, eds. Grounding and Worlding Urban Natures: Histories and Futures of Urban Ecologies. Cambridge: MIT Press (Forthcoming.)

Esposito, Roberto. 2008. Bios: Biopolitics and Philosophy. Minneapolis: University of Minnesota Press.

Fanon, Frantz. 1963. The Wretched of the Earth. New York: Grove Press.

Gandy, Matthew. 2005. "Cyborg Urbanization: Complexity and Monstrosity in the Contemporary City.” International Journal of Urban and Regional Research 29(1): 26-49.

Gandy, Matthew. 2012. "Queer Ecology: Nature, Sexuality, and Heterotopic Alliances." Environment and Planning D: Society and Space 30(4): 727-47.

Garuba, Harry. 2012. "On Animism, Modernity/Colonialism, and the African Order of Knowledge: Provisional Reflections.” E-Flux Journal 36: 1-9.

Green, Lesley. 2015. "The Changing of the Gods of Reason: Cecil John Rhodes, Karoo Fracking and the Decolonizing of the Anthropocene." E-Flux Journal 65: 1-9.

Harman, Graham. 2016. Immaterialism: Objects and Social Theory. Cambridge: Polity Press.

Heynen, Nik. 2014. "Urban Political Ecology I: The Urban Century." Progress in Human Geography 38(4): 598-604.

Heynen, Nik. 2015. “Urban Political Ecology II:The Abolitionist Century.” Progress in Human Geography 40(6): 839-45.

Heynen, Nik. 2017. “Urban Political Ecology III:The Feminist and Queer Century.” Progress in Human Geography 42(3): 446-52.

Heynen, Nik, Maria Kaika, and Erik Swyngedouw, eds. 2006. In the Nature of Cities: Urban Political Ecology and the Politics of Urban Metabolism. London and New York: Routledge.

Hicks, Dam and Mary C. Beaudry, eds. 2010. The Oxford Handbook of Material Culture Studies. Oxford: Oxford University Press.

Huchzermeyer, Marie. 2003. "Housing Rights in South Africa: Invasions, Evictions, the Media and the Courts in the Cases of Grootboom, Alexandra, and Bredell." Urban Forum 14(1): 80-107.

James, Cyril L.R. 1989 [1938]. The Black Jacobins: Toussaint L'Ouverture and the San Domingo Revolution. New York:Vintage Books.

Kaika, Maria. 2005. City of Flows: Modernity, Nature and the City. London and New York: Routledge.

Keil, Roger. 2003. "Progress Report: Urban Political Ecology.” Urban Geography 24(8): 723-38.

Keil, Roger. 2005. "Progress Report: Urban Political Ecology.” Urban Geography, 26(7): 640-51.

Klosek, Kamil. 2018. "Catalysts of Violence: How Do Natural Resource Extractive Technologies Influence Civil War Outbreak and Incidence in Sub-Saharan Africa?" The Extractive Industries and Society 5(2): 344-53. 
Lalu, Premesh. 2009. The Deaths of Hintsa: Postapartheid South Africa and the Shape of Recurring Pasts. Cape Town: HSR C Press.

Latour, Bruno. 2005. Reassembling the Social: An Introduction to Actor-Network-Theory. Oxford: Oxford University Press.

Lawhon, Mary, Henrik Ernstson, and Jonathan Silver. 2014. "Provincializing Urban Political Ecology: Towards a Situated UPE through African Urbanism.” Antipode 46(2): 497-516.

Mamdani, Mahmood. 1996. Citizen and Subject: Contemporary Africa and the Legacy of Late Colonialism. New Jersey and Kampala: Princeton University Press and Fountain Publishers.

Marchart, Oliver. 2007. Post-foundational Political Thought: Political Difference in Nancy, Lefort, Badiou and Laclau. Edinburgh: Edinburgh University Press.

Mbembe, Achille. 2017. Critique of Black Reason. Johannesburg: Wits University Press \& Duke University Press.

Mignolo, Walter D. 2012. Local Histories/Global Designs: Coloniality, Subaltern Knowledges, and Border Thinking. 2nd edn. Princeton and Oxford: Princeton University Press.

Morton, Timothy. 2013. Hyperobjects: Philosophy and Ecology After the End of the World. Minneapolis: University of Minnesota Press.

Neocosmos, Michael. 2012. "Are Those-who-do-not-count Capable of Reason? Thinking Political Subjectivity in the (Neo-)colonial World and the Limits of History." Journal of Asian and African Studies 47(5): 530-47.

Njeru, Jeremia. 2006. "The Urban Political Ecology of Plastic Bag Waste Problem in Nairobi, Kenya.” Geoforum 37(6): 1046-58.

Pellizzoni, Luigi. 2016. "Catching Up With Things? Environmental Sociology and the Material Turn in Social Theory." Environmental Sociology 2(4): 312-321.

Rademacher, Anne. 2015. "Urban Political Ecology." Annual Review of Anthropology 44(1): 137-52.

Ranganathan, Malini. 2014. "Paying for Pipes, Claiming Citizenship: Political Agency and Water Reforms at the Urban Periphery." International Journal of Urban and Regional Research 38(2): 590-608.

Robinson, Jennifer. 2016. "Thinking Cities through Elsewhere: Comparative Tactics for a More Global Urban Studies.” Progress in Human Geography 40(1): 3-29.

Roy, Ananya. 2014. "Worlding the South: Toward a Postcolonial Urban Theory." In The Routledge Handbook on Cities of the Global South, edited by Sue Parnell and Sophie Oldfield, 9-20. London and New York: Routledge.

Roy, Ananya, and Aihwa Ong, eds. 2011. Worlding Cities: Asian Experiments and the Art of Being Global. Oxford: Blackwell Publishing.

Said, Edward. 1983. The World, the Text and the Critic. Cambridge: Harvard University Press.

Schulz, Karsten A. 2017. "Decolonizing Political Ecology: Ontology, Technology and 'Critical' Enchantment.” Political Ecology 24: 125-43.

Silver, Jonathan. 2014. "Incremental Infrastructures: Material Improvisation and Social Collaboration across Post-Colonial Accra.” Urban Geography 35(6): 788-804.

Silver, Jonathan. 2015. "Disrupted Infrastructures: An Urban Political Ecology of Interrupted Electricity in Accra." International Journal of Urban and Regional Research 39(5): 984-1003.

Simone, AbdouMaliq. 2011. City Life from Jakarta to Dakar: Movements at the Crossroads. London: Routledge.

Stengers, Isabelle. 2003. Cosmopolitiques. Paris: La Découverte.

Sutherland, Ewan. 2011. Coltan, the Congo and Your Cell-phone. University of the Witwatersrand, LINK Centre. Accessed on April 29, 2018. http://web.mit.edu/12.000/www/m2016/ pdf/coltan.pdf. 
Swyngedouw, Erik. 1996. "The City as a Hybrid: On Nature, Society and Cyborg Urbanization." Capitalism Nature Socialism 7(2): 65-80.

Swyngedouw, Erik, and Henrik Ernstson. 2018. "Interrupting the Anthropo-obscene: Immuno-biopolitics and Depoliticizing Ontologies in the Anthropocene." Theory, Culture and Society, First Online, February 13, 2018. https://doi.org/10.1177/ 0263276418757314.

Swyngedouw, Erik, and Maria Kaika. 2014. "Urban Political Ecology. Great Promises, Deadlock... and New Beginnings?” Documents d'Anàlisi Geogràfica 60(3): 459-81.

Tansel, Berrin. 2017. "From Electronic Consumer Products to E-wastes: Global Outlook, Waste Quantities, Recycling Challenges.” Environment International 98: 35-45.

Truelove, Yaffa. 2011. (Re-)conceptualizing Water Inequality in Delhi, India through a Feminist Political Ecology Framework. Geoforum 42(2): 143-52.

Watson, Ivan. 2013. "China: The Electronic Wastebasket of the World." CNN International Edition. Accessed on April 29, 2018. https://edition.cnn.com/2013/05/30/world/asia/ china-electronic-waste-e-waste/index.html.

Welfens, Jolanta, Julia Nordmann, and Alexandra Seibt. 2016. "Drivers and Barriers to Return and Recycling of Mobile Phones. Case Studies of Communications and Collection Campaigns." Journal of Cleaner Production 132: 108-121.

Wilson, Japhy, and Erik Swyngedouw, eds. 2014. The Post-political and Its Discontents: Spaces of Depoliticization, Spectres of Radical Politics. Edinburgh: Edinburgh University Press.

Wynter, Sylvia. 1995. "1492: A New World View." In Race, Discourse, and the Origin of the Americas: A New World View, edited by Vera Lawrence Hyatt and Rex Nettleford, 5-57. Washington DC: Smithsonian Institution Press. 


\section{URBAN POLITICAL \\ ECOLOGY IN THE \\ ANTHROPO-OBSCENE}

\section{Interruptions and Possibilities}

Edited by Henrik Ernstson and Erik Swyngedouw 
First published 2019

by Routledge

2 Park Square, Milton Park, Abingdon, Oxon OX14 4RN

and by Routledge

711 Third Avenue, New York, NY 10017

Routledge is an imprint of the Taylor \& Francis Group, an informa business

(C) 2019 selection and editorial matter, Henrik Ernstson and Erik Swyngedouw; individual chapters, the contributors

The right of Henrik Ernstson and Erik Swyngedouw to be identified as the authors of the editorial material, and of the authors for their individual chapters, has been asserted in accordance with sections 77 and 78 of the Copyright, Designs and Patents Act 1988.

All rights reserved. No part of this book may be reprinted or reproduced or utilised in any form or by any electronic, mechanical, or other means, now known or hereafter invented, including photocopying and recording, or in any information storage or retrieval system, without permission in writing from the publishers.

Trademark notice: Product or corporate names may be trademarks or registered trademarks, and are used only for identification and explanation without intent to infringe.

British Library Cataloguing-in-Publication Data

A catalogue record for this book is available from the British Library

Library of Congress Cataloging-in-Publication Data

A catalog record has been requested for this book

ISBN: 978-1-138-62918-9 (hbk)

ISBN: 978-1-138-62919-6 (pbk)

ISBN: 978-1-315-21053-7 (ebk)

Typeset in Bembo

by Out of House Publishing 


\section{PREFACE AND ACKNOWLEDGEMENTS}

Urban Political Ecology in the Anthropo-obscene: Interruptions and Possibilities aims to expand the study of urbanization and environmental politics through the field of urban political ecology (UPE). In particular, the book centres on developing ways to engage more explicitly with the pressing question of how to organize anew the articulation between emancipatory theory and political activism. While our initial name for this project was UPE+20, which marked 20 plus years after the 1996 article by Erik Swyngedouw on The City as a Cyborg, a key article in the early days of the field, the book is not intended to take stock of the field, nor do a systematic review. ${ }^{1}$ Rather it calls for bringing back "the political" centre-stage into our study and engagement with the world. We notice with delight how the contributions in this book extend in provocative and novel ways how UPE and associated fields can be re-thought in the coming years. Above-all, we see a wider conversation emerging that links critical geography and urban studies, the origins of UPE, with critical race and postcolonial theory, and-importantly, with political theory and action.

As the editors, we would like to stretch out a heartfelt thanks to our colleagues for their contributions to this volume: Marco Armiero, Jodi Dean, Sapana Doshi,Andrés Fabián Henao Castro, Nik Heynen, Maria Kaika, Roger Keil, Andy Merrifield, Jason W. Moore, Garth Myers, Malini Ranganathan, Jonathan Silver, and Richard Walker. Representing different disciplines and generations of scholars, they have shared from their vast field experience and theoretical interests and demonstrated a steadfast commitment and dedication to this project. We are grateful for how they elegantly shaped their chapters so that each carry their particular style, while speaking to the broader themes of the book. It is of course our colleagues and their contributions that have made possibly this stimulating and important volume. We also send a special thanks to Edgar Pieterse who contributed to our initial discussions. 
We thank eminent theatre director Kent Ekberg and producer Kajsa Nordin in Stockholm for their playful and artful solidarity with our project in its early stage. We also thank Mexican illustrator and artist Carlos Carmonamedina based in Washington D.C. for offering his artwork for the cover illustration, and we thank Bruce Baigrie in Cape Town for diligent and tireless preparation of the manuscript for submission. Our Routledge Editor Andrew Mould and Editorial Assistant Egle Zigaite need our praise for their continuous, generous and helpful support throughout this whole process.

The labour time involved in a project like this is extensive. The first editor acknowledges generous economic support from the Marcus and Amalia Wallenberg Foundation, which made this book possible, and he thanks the Swedish Research Council Formas (Dnr: 211-2011-1519; MOVE) for providing funds for travels and meetings. Both editors acknowledge support from the UK's Economic and Social Research Council (Grant ref: ES/M009408/1;TLR) and we thank our institutions for providing collegial spaces in which we could discuss various parts of this book, including the Department of Geography at The University of Manchester, KTH Environmental Humanities Laboratory at KTH Royal Institute of Technology, and the African Centre for Cities at the University of Cape Town.

The first editor would also like to specially thank Andrea Eckstein for her support throughout, and, when the second editor visited Cape Town, for sharing dinners and her insights as a therapist of Cape Town's many psychosocial forms of oppression, liberations and idiosyncrasies.

Henrik Ernstson and Erik Swyngedouw Cape Town and Manchester, January and May 2018

\section{Note}

1 See Swyngedouw, Erik. 1996. "The City as a Hybrid: On Nature, Society and Cyborg Urbanization.” Capitalism Nature Socialism 7(2): 65-80. 
